\title{
STRATEGI MANAJEMEN HUMAS DALAM MENCIPTAKAN SCHOOL BRANDING PADA SEKOLAH ISLAM TERPADU
}

\author{
Tutut Sholihah \\ IAIN Palangka Raya \\ Email: sholihahplk21@gmail.com
}

\begin{abstract}
More and more quality schools have created intense competition in the management of educational institutions. To be able to compete, the school branding strategy is very important for schools primarily in private schools. SDIT Al-Furqan and SMPIT Al-Ghazalii Palangka Raya became the location of the study because it is one of the private schools that offers quality oriented to Islam, and has made rapid progress with various advantages, incised many achievements both in academic and non-academic terms, increasing number of participants each year. The problem raised in this study is how to plan public relations strategy, how to implement the public relations management strategy and how the results of implementing the public relations management strategy in creating School Branding in both schools. This study aims to describe and analyze the planning of public relations management strategies, implementation of the public relations management strategy and how the results of its implementation in creating School Branding at SDIT Al-Furqan and SMPIT Al-Gazali Palangka Raya, and to offer a concept of public relations management strategies in creating School Branding at Integrated Islamic schools. The study was conducted using a descriptive qualitative approach, data was collected through interviews, observation and documentation studies. The main subjects are principals, public relations, parents of students, heads of administration, teachers, and the community. The results of this study reveal that: 1) Public relations management strategy planning is designed and organized together with principals, divisions and public relations by considering all aspects until the school brand can reach the community, 2) Implementation of public relations management strategies carried out in accordance with the schedule organized by conducting promotions and publications in print media, electronic media, and social media, as well as communicating and socializing directly to the public, 3) The results of the public relations management strategy can be seen in the indicators of the success of schools becoming well-known in the community, creating a positive image for school, students increase every new school year, become a favorite and superior school.
\end{abstract}

Keywords. Strategy, Public Relations, School Branding, Integrated Islamic School

Abstrak. Semakin banyak sekolah yang berkualitas telah menciptakan persaingan yang ketat dalam pengelolaan lembaga pendidikan. Untuk dapat bersaing, strategi branding sekolah menjadi sangat penting bagi sekolah-sekolah utamanya pada sekolah swasta. SDIT Al-Furqan dan SMPIT Al-Ghazalii Palangka Raya menjadi lokasi penelitian karena sebagai salah satu sekolah swasta yang menawarkan mutu dengan berorientasi pada Islam, dan telah mengalami kemajuan yang pesat dengan berbagai keunggulan, banyak menorehkan prestasi baik dari segi akademik dan non akademik, meningkatnya jumlah perserta didik tiap tahun. Masalah yang diangkat pada penelitian ini adalah bagaimana perencanaan strategi humas, bagaimana implementasi dari startegi manajmen humas tersebut dan bagaimana hasil dari penerapan strategi manajemen humas tersebut dalam menciptakan School Branding 
pada kedua sekolah tersebut. Penelitian ini bertujuan mendeskripsikan serta menganalisa perencanaan strategi manajemen humas, implementasi dari startegi manajemen humas tersebut dan bagaimana hasil dari penerapannya dalam menciptakan School Branding di SDIT Al-Furqan dan SMPIT Al-Gazali Palangka Raya, serta untuk menawarkan sebuah konsep model strategi manajemen humas dalam menciptakan School Branding pada sekolah Islam Terpadu. Penelitian dilakukan dengan menggunakan pendekatan kualitatif deskriptif, data dikumpulkan melalui wawancara, observasi dan studi dokumentasi. Subjek utama adalah kepala sekolah, humas, orang tua siswa, kepala tata usaha, para guru, dan masyarakat. Hasil penelitian ini mengungkapkan bahwa : 1) Perencanaan strategi manajemen humas di rancang dan di susun bersama dengan kepala sekolah, divisi dan humas dengan mempertimbangkan semua aspek hingga brand sekolah bisa sampai pada masyarakat, 2) Implementasi dari strategi manajemen humas dilakukan humas sesuai jadwal yang telah di susun dengan melakukan promosi dan publikasi ke media cetak, media elektronik, dan sosial media, serta berkomunikasi dan sosialisasi ke publik secara langsung, 3) Hasil dari strategi manajemen humas tersebut terlihat dengan adanya indikator keberhasilan sekolah menjadi terkenal di masyarakat, tercipta image positif bagi sekolah, peserta didik bertambah setiap tahun ajaran baru, menjadi sekolah favorit dan unggulan.

Kata kunci. Strategi, Humas, School Branding, Sekolah Islam Terpadu Copyright (C JMPI: Jurnal Manajemen Pendidikan Islam. All Right Reserved. This is an open access article under the CC BY-NC-ND license (http://creativecommons.org/licenses/by-nc-nd/4.0/).

\section{A. PENDAHULUAN}

Seiring berjalannya waktu dari tahun ke tahun dunia pendidikan pun mengalami banyak fenomena, salah satunya bermunculan sekolah-sekolah baru terutama sekolah swasta yang ini pastinya memunculkan adanya persaingan antar sekolah baru tersebut maupun sekolah swasta yang sudah lama berdiri dan masingmasing sekolah berebut untuk membuat citra positif di tengah masyarakat. Untuk itu di perlukan berbagai macam startegi dari sekolah dalam mengenalkan sekolah pada publik.

Brand alias merek bagi sekolah bukan sekedar nama dan lokasi melainkan sebuah identitas untuk dikenal dan dapat dibedakan mutu pelayanannya dari sekolah lain. Strategi branding sekolah menjadi sangat penting bagi sekolah-sekolah utamanya pada sekolah swasta (Wahyudi, 2015). Karena itu sekolah harus mampu menampilkan proses pelayanan pendidikan melalui atribut kegiatan belajar mengajar yang unik, meliputi mutu KBM, kepuasan belajar siswa, prestasi siswa dan mutu out come. Sekolah juga mampu memberi kesan yang mendalam kepada siswa dan masyarakat tentang manfaat bersekolah di tempat tersebut. Siswa dan masyarakat mendapatkan "value" bersekolah (brand value), bukan hanya akademik, namun juga daya saing dan akhlak mulia. Sekaligus sekolah dapat membidik "costumer" yang menjadi target market-nya (Santoso, 2012). Humas mutlak ada dalam sebuah institusi atau lembaga pendidikan, karena keberadaan humas tersebut adalah untuk membangun branding dan reputasi sekolah (Setyanto, Anggarina, \& Valentina, 2017). 
Pengertian Manajemen Humas menurut definisi kamus terbitan Institute of Public Telations (IPR), yakni sebuah lembaga humas terkemuka di Inggris dan Eropa, terbitan bulan November 1987 seperti yang dikutip Anggoro(2000) adalah keseluruhan upaya yang dilangsungkan secara terencana dan berkesinambungan dalam rangka menciptakan dan memelihara niat baik dan saling pengertian antara suatu organisasi dengan segenap khalayaknya. Jadi, humas adalah suatu rangkaian kegiatan yang diorganisasi sedemikian rupa sebagai suatu rangkaian kampanye atau program terpadu, dan semuanya itu berlangsung secara berkesinambungan dan teratur. Kegiatan humas sama sekali tidak bisa dilakukan secara sembarangan atau amatiran. Tujuan humas itu sendiri adalah untuk memastikan bahwa niat baik dan kiprah organisasi yang bersangkutan senantiasa dimengerti oleh pihak-pihak lain yang berkepentingan (atau lazim disebut sebagai seluruh "khalayak" atau publiknya). Di dalam khazanah Islam kata "humas" memang jarang terpakai baik dalam bahasa tulisan maupun lesan. Namun ada dua kata yang memiliki makna yang sama yaitu "habl" yang artinya "tali atau hubungan" atau "silaturrahim" yang artinya "menyambung persaudaraan" yang sering digunakan dalam bahasa khazanah keislaman. Penggunaan kata habl ini sebagaimana firman Allah:

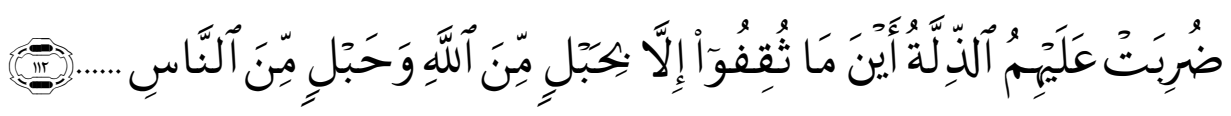

Mereka diliputi kehinaan di mana saja mereka berada, kecuali jika mereka menjalin hubungan kepada (agama) Allah dan menjalin hubungan terhadap sesama manusia, ... (QS. Ali Imran [3]: 112).

Berdasarkan definisi diatas maka humas dalam pengembangan Lembaga Pendidikan Islam dapat diartikan sebagai kegiatan manajemen yang lebih memfokuskan pada kegiatan komunikasi yang lebih terarah antara lembaga pendidikan dan masyarakat melalui langkah-langkah: saling mengenal, saling memahami, saling mengasihi, saling bermusyawarah, saling menolong dan saling menanggung; sehingga terwujud kerjasama yang baik dan saling menguntungkan kepada pihak-pihak yang terkait, dengan tujuan utamanya untuk meningkatkan mutu pendidikan dan menghasilkan lulusan sebagaimana yang dicita-citakan.

Menurut Triwiyanto (2015) banyak upaya atau strategi yang dapat dilakukan untuk melakukan school branding atau pencitraan publik terhadap sekolah. Upaya atau strategi pencitraan sekolah tersebut adalah sebagai berikut:

1) Peningkatan kerja kepala sekolah, pendidik, dan tenaga kependidikan.

2) Keikutsertaan sekolah dalam kegiatan-kegiatan lomba sekolah dan siswa.

3) Membangun jaringan kerja (network) dengan orang tua murid dan masyarakat.

4) Peningkatan layanan akademik dan non-akademik yang prima.

5) Kepemilikan peringkat akreditasi sekolah yang baik

Sedangkan menurut Gunawan (2016), ada banyak teknik yang dapat dipergunakan oleh sekolah dalam melakukan pencitraan publik maupun stakeholders-nya, yaitu: (1) pameran sekolah; (2) publikasi kegiatan positif sekolah; (3) pertemuan sekolah dengan orang tua dan tokoh masyarakat; (4) jurnalisme warga sekolah (school citizen journalist); (5) konferensi pers; (6) website sekolah; (7) gelar prestasi sekolah; (8) testimoni elit tentang prestasi sekolah; (9) pelibatan warga 
sekolah dalam kepemimpinan publik (masyarakat); (10) bakti sosial sekolah; dan (11) membuat berbagai event dan kegiatan yang mampu memobilisasi masyarakat. Menurut Gunawan (2016), pencitraan sekolah (school branding) bukan dimaksudkan untuk mengemas ketidakbaikan sekolah menjadi terkesan baik, melainkan untuk mengemas dengan baik apa yang sudah dikerjakan oleh sekolah untuk dikomunikasikan kepada publik. Diharapkan, hal-hal positif yang sudah diperbuat tersebut, diketahui oleh publik dengan keadaan yang senyatanya. Dengan demikian, efek positif pencitraan publik sekolah dasar yang dikehendaki menurut Imron dalam Gunawan (2016) adalah: 1) Publik mengetahui program, implementasi program, dan apa saja yang telah dilakukan oleh sekolah. 2) Publik mempersepsi positif terhadap program, implementasi program, dan apa saja yang telah dilakukan oleh sekolah. 3) Publik percaya (trust) terhadap amanat untuk mendidik anak yang dilakukan oleh sekolah. 4) Publik merasa memiliki (sens of belongingness) terhadap apa saja yang telah dilakukan oleh sekolah. 5) Publik memberikan respon positif, kritik konstruktif, dan masukan berharga bagi kemajuan sekolah. 6) Publik bersedia memberikan dukungan (support) dan bantuan baik material maupun moral untuk kemajuan sekolah. 7) Publik akan secara terus menerus mengawal sekolah agar berkinerja sesuai dengan yang diharapkan.

Lebih lanjut Santoso (2010) menjelaskan srategi branding bagi sekolah untuk kompetensi akademik peserta didik meliputi kualitas curiosity dan creativity. Kepala Sekolah selayaknya menentukan competitive marketing planning dengan mempertimbangkan antrophologi dan segmentasi peserta didiknya melalui penyusunan strategi value misi dan visi sekolah. Untuk meningkatkan competitive advantage peserta didik sekolah semestinya memiliki program tutorial keberbakatan siswa. Baik untuk prestasi akademik maupun ekstra kurikuler yang lainnya. Berbagai kompetisi yang diikuti peserta didik dapat meningkatkan rasa percaya diri dan daya saingnya.

Dalam era persaingan yang selalu memerlukan daya inovasi dan kreativitas adalah perlunya dikembangkan sekolah sebagai organisasi pembelajar. Hal ini sebagaimana pemikiran Argyris yang menekankan perlunya membangun organisasi pembelajar. Hal ini berarti dalam setiap langkah interaktif sehari-hari di sekolah harus didesain sebagai sebuah proses untuk meningkatkan kapasitas kompetensi dalam meningkatkan etos kerja sekolah dengan indikator secara umum, seperti yang diungkapkan Rivai dan Ahmad Fauzi (2004) dalam Sholihah (2012) sebagai berikut: 1) Motivasi kinerja; 2) Dampak kinerja pada hasil (dalam hal ini kinerja belajar siswa); 3) Berpikir strategis; 4) Berpikir kreatif; 5) Berpikir realistis; 6) Berpikir tepat; 7) Berpikir ikhlas; 8) Meningkatkan efektivitas hubungan pribadi; 9) Meningkatkan efektivitas komunikasi; 10) Meningkatkan kompetensi untuk mengatasi perubahan; 11) Meningkatkan kompetensi untuk merencanakan, melaksanakan dan mengevaluasi pekerjaan.

Berdasarkan dari beberapa pendapat tersebut maka dapat disimpulkan bahwasannya pencitraan sekolah (school branding) bukan dimaksudkan untuk mengemas ketidakbaikan sekolah menjadi terkesan baik, melainkan untuk mengemas dengan baik apa yang sudah dikerjakan oleh sekolah untuk dikomunikasikan kepada publik. Diharapkan, hal-hal positif yang sudah diperbuat tersebut, diketahui oleh publik dengan keadaan yang senyatanya. Dengan citra positif sekolah inilah 
diharapkan mampu menarik publik untuk lebih mengenal visi-misi sekolah dan tentunya diharapkan menyekolahkan putra-putrinya di sekolah tersebut.

Terkait dengan konteks tersebut maka peneliti ingin mengkaji lebih mendalam dengan fokus penelitian: Bagaimana strategi manajemen humas dalam mewujudkan school branding pada Sekolah Islam Terpadu dengan mengambil studi multi situs pada Sekolah Dasar Islam Terpadu (SDIT) Al-Furqan Palangka Raya dan Sekolah Menengah Pertama Islam Terpadu (SMPIT) Al-Ghazali Palangka Raya. Adapun tujuan penelitian ini adalah sebagai berikut:

1. Mendeskripsikan perencanaan strategi manajemen humas dalam menciptakan school branding pada Sekolah Islam Terpadu pada SD Islam Terpadu Al-Furqan Palangka Raya dan SMP Islam Terpadu Al-Ghazali Palangka Raya.

2. Mendeskripsikan implementasi strategi manajemen humas dalam menciptakan school branding pada Sekolah Islam Terpadu pada SD Islam Terpadu Al-Furqan Palangka Raya dan SMP Islam Terpadu Al-Ghazali Palangka Raya.

3. Mendeskripsikan hasil strategi manajemen humas dalam menciptakan school branding pada Sekolah Islam Terpadu pada SD Islam Terpadu Al-Furqan Palangka Raya dan SMP Islam Terpadu Al-Ghazali Palangka Raya

\section{B. METODE}

Penelitian ini menggunakan paradigma alamiah (naturalistic paradigm) dengan jenis pendekatan kualitatif atau studi kasus (case study). Desain penelitian berkembang selama proses penelitian berlangsung. Dengan penelitian kualitatif, peneliti menilai bahwa strategi manajemen humas dalam mewujudkan school branding pada Sekolah Islam Terpadu di SD IT Al-Furqan dan SMP IT Al-Ghazali Kota Palangka Raya adalah tindakan yang manusiawi, karena setiap pelaku sebagai makhluk berkesadaran, yang tindakan-tindakannya bersifat intensional, melibatkan interpretasi dan pemaknaan.

Dengan penelitian kualitatif, menurut Faisal (2000), peneliti berusaha memandang manusia sebagai makhluk berkesadaran, yang tindakan-tindakannya bersifat intensional, melibatkan interpretasi dan pemaknaan. Berdasarkan pandangan tersebut, peneliti menyakini bahwa tindakan atau "perilaku" manusia bukanlah suatu reaksi yang bersifat otomatis dan mekanistik ala stimulus respon sebagaimana aksioma behaviorisme, melainkan suatu pilihan yang "diniati" berdasarkan kesadaran, interpretasi dan makna-makna tertentu

\section{Lokasi Penelitian}

Penelitian ini mengambil lokasi pada SD Islam Terpadu Al-Furqan dan SMP Islam Terpadu Al-Ghazali Kota Palangka Raya. Pertama, Sekolah Dasar Islam Terpadu (SDIT) Al-Furqan Kota Palangka Raya, yang berlokasi di jalan Murai No. 1-B Palangkaraya Kalimantan Tengah, admin-sdit@sdit-alfurqon,sch,id; http://sditalfurqon.sch.id. Kedua, SMP Islam Terpadu (SMPIT) Al-Ghazali Modern School beralamat di Jl. Rajawali VII, Bukit Tunggal, Jekan Raya, Kota Palangka Raya, Kalimantan Tengah. SD Islam Terpadu Al-Furqan didirikan pada tahun 2007 sehingga usianya sekitar 10 tahun dan SMP Islam Terpadu Al-Ghazali didirikan pada tahun 2013 sehingga usianya sekitar 5 tahun. Walaupun kedua sekolah Islam tersebut belum lama berdiri namun karena berbagai kualitas pendidikan dan pembelajarannya termasuk didukung oleh strategi manajemen humas yang tepat maka kedua sekolah 
telah mendapat branding atau citra yang baik dari masyarakat muslim kelas menengah di kota Palangka Raya. Dari alasan utama inilah maka peneliti memilih kedua sekolah tersebut sebagai lokasi penelitian.

\section{Informan Penelitian}

Dalam penelitian kualitatif, kata sumber data disebut informan penelitian. Secara rinci pengambilan lokasi, situasi sosial dan informan yang menjadi subyek penelitian ini yaitu Humas, Pengurus Yayasan, Kepala Sekolah, Wakil Kepala Sekolah, Wali Kelas, Dewan Guru, para Pembina kegiatan ekstrakurikuler, para TU, Komite Sekolah, Wali Murid, media massa lokal dan berbagai pihak yang terkait dengan aktivitas kedua sekolah tersebut.

\section{Teknik dan Prosedur Pengumpulan data}

Pengumpulan data adalah prosedur yang sistematik dan standar untuk memperoleh data yang diperlukan (Ahmad Tanzeh, 2009). Pada penelitian kualitatif, pada dasarnya teknik pengumpulan data yang lazim digunakan adalah observasi partisipan, wawancara mendalam, dan dokumentasi. Kegiatan pengumpulan data yang dilakukan dengan observasi dan wawancara mendalam untuk menjelajahi dan melacak secara memadai terhadap realitas fenomena yang tengah distudi (Burhan Bungin, 2005).

Maka dalam penelitian ini, peneliti menggunakan tiga teknik tersebut, yaitu:

a) Observasi: Langkah awal yang dilakukan peneliti adalah melakukan observasi ke sekolah yang menjadi tempat penelitian.

b) Wawancara: Langkah berikutnya peneliti melakukan wawancara kepada pihak-pihak yang terkait dengan fokus masalah dalam penelitian ini. Wawancara adalah metode yang dilakukan melalui dialog secara langsung antara pewawancara (interviewer) dengan pihak yang akan dimintai keterangan untuk memperoleh data atau informasi yang dibutuhkan.

c) Dokumentasi Teknik selanjutnya adalah melakukan pengumpulan data dengan dokumentasi. Dokumentasi adalah salah satu metode yang digunakan untuk mencari data otentik yang bersifat dokumentasi baik data itu berupa catatan harian, memori atau catatan lainnya, dokumentasi berupa gambar misalnya foto, gambar hidup, video, sketsa dan lain sebagainya (Burhan Bungin, 2005).

\section{Teknik Analisis Data}

Penelitian ini menggunakan teknik analisis data model interaktif seperti yang dikembangkan oleh Miles dan Huberman(1992). Analisis data berlangsung secara simultan yang dilakukan bersamaan dengan proses pengumpulan data, dengan alur tahapan: (1) pengumpulan data (data collection), (2) reduksi data (data reduction), (3) penyajian data (data display), dan (4) kesimpulan atau verifikasi (conclution drawing $\mathcal{E}$ verifying).

\section{HASIL}

\section{Hasil temuan pada penelitian strategi manajemen humas dalam menciptakan} school branding pada sekolah Islam terpadu SDIT Al-Furqan

Bahwa di SDIT AL-Furqan Palangka Raya untuk strategi manajemen humas dalam menciptakan school branding dilihat dari hasil temuan penelitian mengacu pada masalah didapatkan bahwa dimulai dengan perencanaan strategi manajemen, 
implementasi dari strategi manajemen humas tersebut dan hasil atau dampak yang di terlihat dengan adanya strategi manajemen humas bagi kedua sekolah.

Berikut gambaran strategi manajemen humas mulai dari perencanaan, implementasinya hingga hasil/dampak bagi sekolah dengan adanya strategi manajemen humas dalam menciptakan school branding:

a) Perencanaan Strategi Manajemen Humas Dalam Mewujudkan School Branding di SD Islam Terpadu Al-Furqan Palangka Raya

Temuan awal dalam melihat perencanaan School Branding di sekolah ini mulai dari struktur kepengurusan sekolah yang terstruktur, kerja tim yang solid untuk mensuskseskan setiap program sekolah yang sudah dibuat, serta penyusunan program kerja masing-masing pengurus yang variatif dan inovatif demi kesuksesan dan terlaksananya strategi humas.

Perencanaan strategi dimulai dari adanya koordinasi dari kepala sekolah untuk mengarahkan humas, divisi, guru, TU, kemudian diadakan rapat penyusunan progja, kegiatan dan strategi-strategi humas, setelah rapat humas kemudian bersiap untuk melaksanakan time schedule dan menyiapkan team untuk segera bergerak. Team mempersiapkan alat, bahan untuk segera melakukan strategi pemasaran dengan promosi dan sosialisasi menentukan target-target. Gambaran perencanaannya dapat dilihat dalam gambar 2.1 sebagai berikut :

Gambar 2.1

Perencanaan Strategi Manajemen Humas SDIT Al Furqon
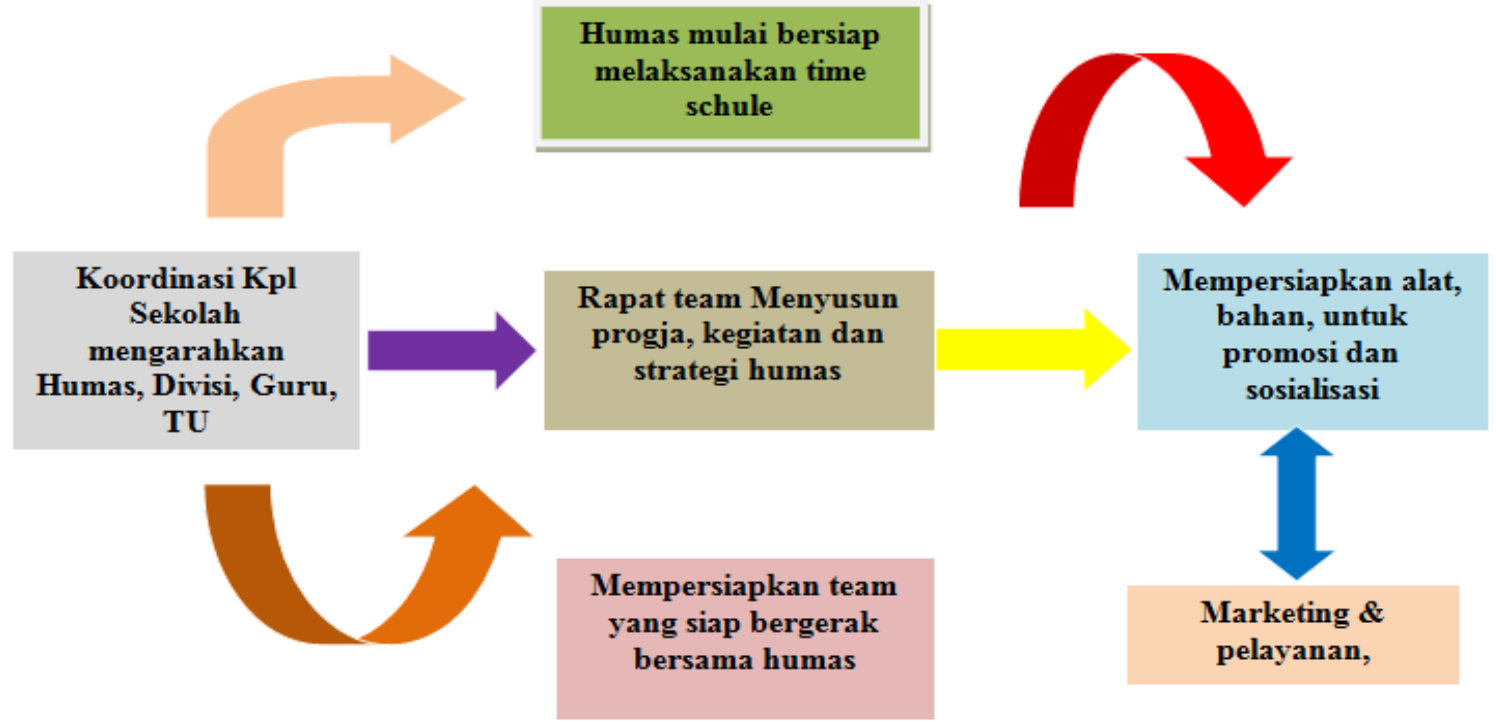

\section{b) Implementasi Strategi Manajemen Humas Dalam Mewujudkan School Branding} di SD Islam Terpadu Al-Furqan Palangka Raya

Implementasi dari strategi yang telah direncanakan oleh team sebagai berikut :

1) Rapat koordinasi tentang program kerja sekolah

2) Humas melakukan komunikasi dan bertemu langsung dengan berbagai lapisan masyarakat

3) Melaksanakan seluruh program sekolah 
4) Mengkomunikasikan semua Keunggulan sekolah pada proses belajar mengajar yang berbasis Information and Communication Technologies (ICT)

5) Melakukan kerjasama dengan berbagai lembaga dengan bentuk penandatangan Mou

6) Melakukan pengenalan sekolah pd kegiatan diluar sekolah, misal ikut perlomban dll

7) Melaksanakan program sekolah eksternal agar lebih dikenal oleh masyarkat yaitu bakti sosial dan bazaar

8) Mengikuti kelompok kkg, mgmp, kks untuk lebih di kenal di tengah-tengah sekolah yang lain

9) Publikasi kegiatan, program sekolah dengan pembuatan film dokumenter dan dikirim ke sosial media seperti Instagram, FB, WA, You tobe, videotron

10) Pembuatan iklan melalui media cetak koran, radio, televisi, menyebarkan brosur, spanduk ke sekolah-sekolah, instansi, masyarakat langsung

c) Hasil atau dampak dengan adanya Strategi Manajemen Humas Dalam Mewujudkan School Branding di SD Islam Terpadu Al-Furqan Palangka Raya Adapun hasil ataupun dampak adanya Strategi Manajemen Humas Dalam Mewujudkan School Branding pada sekolah ini adalah sebagai berikut :

1) Bahwa brand/citra baik sekolah sudah dikenal masyarakat

2) Meningkatnya jumlah peserta didik setiap tahun ajaran baru

3) Terbentuknya image positif pada sekolah di tengah masyarakat

4) Tersampaikannya bahwa sekolah memiliki keunggulan dalam berbagai bidang ditengah masyarakat

5) Meningkatnya kepercayaan dan dukungan pemerintah dan lembaga-lembaga swasta.

6) Menjadi Sekolah Islam Terpadu yang memiliki school branding sebagai salah satu sekolah swasta alternatif yang bermutu

\section{Hasil temuan pada penelitian strategi manajemen humas dalam menciptakan} school branding pada sekolah Islam terpadu SMPIT Al-Ghazali

Bahwa SMPIT Al-Ghazali Palangka untuk strategi manajemen humas dalam menciptakan school branding dilihat dari hasil temuan penelitian mengacu pada masalah didapatkan bahwa dimulai dengan perencanaan strategi manajemen, implementasi dari strategi manajemen humas tersebut dan hasil atau dampak yang di terlihat dengan adanya strategi manajemen humas bagi kedua sekolah.

Berikut gambaran strategi manajemen humas mulai dari perencanaan, implementasinya hingga hasil/dampak bagi sekolah dengan adanya strategi manajemen humas dalam menciptakan school branding:

a) Perencanaan strategi manajemen humas dalam menciptakan school branding pada sekolah Islam terpadu SMPIT Al-Ghazali

Untuk melaksanakan strategi humas, maka di perlukan adanya perencanaan terlebih dahulu, di SMPIT Al-Ghazali yayasan yang di dalamnya juga ada penjamin mutunya selalu ikut serta dalam perkembangan sekolah. Perencanaan itu di mulai dari koordinasi antara penjamin mutu dan kepala sekolah kemudian diadakan rapat bersama team yaitu divisi, humas, para guru, TU untuk menyusun strategi humas 
dalam menciptakan school branding, kemudian dibuat lah rencana kerja humas persemester dan pertahun, penganggaran dana dan penetapan time schedul, humas kemudian bersama team mulai melaksanakan strategi humas dalam mempromosikan brand sekolah, keunggulan, citra sekolah ketengah masyarakat memalui berbagai pemasaran. Gambaran perencanaannya bisa dilihat dalam gambar 2.2 berikut:

Gambar 2.2

Perencanaan Strategi Manajemen Humas SMPIT Al-Ghazali

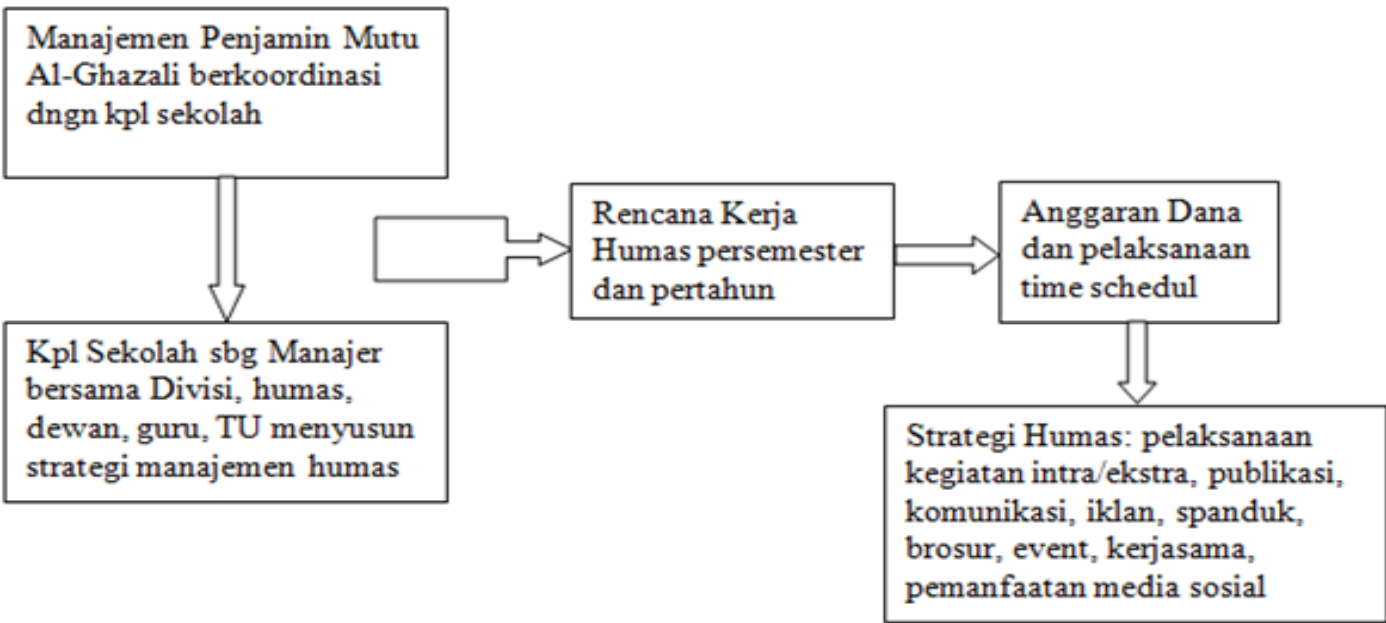

b) Implementasi strategi manajemen humas dalam menciptakan school branding pada sekolah Islam terpadu SMPIT Al-Ghazali

Adapun implementasi dari strategi humas adalah sebagai berikut:

1) Melakukan rapat koordinasi dengan orang tua/wali murid

2) Kegiatan pihak sekolah dan orang tua siswa

3) Pengenalan sekolah kepada siswa baru.

4) Mempublis keunggulan-keunggulan sekolah melalui media-media

5) Pencapaian prestasi dengan berhasil mendapatkan akreditasi A

6) Keunggulan sekolah pada proses belajar mengajar yang berbasis Information and Communication Technologies (ICT), sistem pengajaran yang menyenangkan oleh SDM (para guru) sesuai kualifikasi pendidikannya, berbasis tauhid, unggul dalam prestasi, peduli lingkungan

7) Publikasi kegiatan, program sekolah dengan pembuatan film dokumenter untuk dikirim dan dibagikan ke sosial media seperti Instagram, FB, WA, Youtobe, videotron, ,

8) Pembuatan iklan melalui media cetak koran, radio, televisi, menyebarkan brosur, spanduk ke sekolah-sekolah, instansi, kontak dengan masyarakat langsung

9) Sekolah mengikuti kelompok kkg, mgmp, kks untuk lebih di kenal di tengahtengah sekolah yang lain

10) Mengundang pejabat, tokoh masyarakat pada acara ataupun kegiatan yang diadakan sekolah

c) Hasil atau dampak dari strategi manajemen humas dalam menciptakan school branding pada sekolah Islam terpadu SMPIT Al-Ghazali 
1) Image sekolah favorit dan bermutu dan di minati masyarakat itupun sudah melekat pada sekolah ini

2) Meningkatnya jumlah peserta didik setiap tahun ajaran baru

3) Sekolah yang Islami, mencetak generasi yang cerdas, berakhlaq, beprestasi, dan peduli lingkungan sebagai citra positif sekolah bisa sampai ketengah masyarakat melalui strategi humas dan team work sekolah melalui media massa dalam bentuk kerjasama, serta media sosial

4) Terbentuknya citra positif ditengah masyarakat terhadap sekolah

5) Meningkatnya kepercayaan dan dukungan pemerintah dan lembaga-lembaga swasta

6) Menjadi Sekolah Islam Terpadu yang memiliki school branding sebagai salah satu sekolah swasta alternatif yang terfavorit dan bermutu

\section{E. PEMBAHASAN}

Berdasarkan hasil penelitian, pada bab ini akan di bahas analisis temuan peneliti di SDIT Al Furqan Palangka Raya dan SMPIT Al-Ghazali Palangka Raya tentang Strategi manajemen humas dalam menciptakan school branding yang di laksanakan di kedua sekolah ini. Merujuk pada ruang lingkup strategi manajemen yang merupakan salah satu penentu keberhasilan sekolah mengenalkan citra positif sekolah hingga menumbuhkan persepsi dan image baik di publik.

Salah satu fungsi manajemen adalah hubungan masyarakat, yang akronimnya: "HUMAS" atau "Public Relation" yang sering disingkat "PR. Menurut Triwiyanto (2015) banyak upaya atau strategi yang dapat dilakukan untuk melakukan school branding atau pencitraan publik terhadap sekolah. Upaya atau strategi pencitraan sekolah tersebut adalah sebagai berikut:

1) Peningkatan kerja kepala sekolah, pendidik, dan tenaga kependidikan.

2) Keikutsertaan sekolah dalam kegiatan-kegiatan lomba sekolah dan siswa.

3) Membangun jaringan kerja (network) dengan orang tua murid dan masyarakat.

4) Peningkatan layanan akademik dan non-akademik yang prima.

5) Kepemilikan peringkat akreditasi sekolah yang baik.

Menurut Gunawan (2016), ada banyak teknik yang dapat dipergunakan oleh sekolah dalam melakukan pencitraan publik maupun stakeholders-nya, yaitu: (1) pameran sekolah; (2) publikasi kegiatan positif sekolah; (3) pertemuan sekolah dengan orang tua dan tokoh masyarakat; (4) jurnalisme warga sekolah (school citizen journalist); (5) konferensi pers; (6) website sekolah; (7) gelar prestasi sekolah; (8) testimoni elit tentang prestasi sekolah; (9) pelibatan warga sekolah dalam kepemimpinan publik (masyarakat); (10) bakti sosial sekolah; dan (11) membuat berbagai event dan kegiatan yang mampu memobilisasi masyarakat

Berdasarkan hasil penelitian yang dilakukan di Sekolah Dasar Islam Terpadu Al-Furqan Palangka Raya dan Sekolah Menengah Pertama Islam Terpadu Al-Ghazali Palangka Raya tentang bagaimana Strategi Humas Dalam Menciptakan School Branding pada sekolah Islam Terpadu dan dikaitkan dengan teori-teori dari para ahli didapatkan bahwa, dalam hal perencanaan strategi humas telah terprogram dan terencana, implementasi dari strategi humas juga berjalan sesuai program kerja yang di susun, sehingga dapat dilihat dari hasil atau dampak strategi humas tersebut kedua sekolah tersebut telah sukses dalam membangun citra positif sekolah ditengah 
masyarakat. Keberhasilan ini tidak lepas dari peran kepala sekolah sebagai leader, divisi-divisi yang menyusun program kerja, para guru yang terlibat dalam mensukseskan setiap kegiatan, tata usaha yang mengurus masalah administrasi, hingga terlaksananya strategi humas dalam mewujudkan School Branding pada sekolah Islam terpadu.

Dengan demikian arah pengembangan SDIT Al-Furqan dan SMPIT Al Ghazali Palangkaraya memiliki peran penting dalam proses pengembangan pendidikan sekolah dasar dan menengah pertama yang mampu memberikan imbas positif terhadap perkembangan sekolah Islam yang ada di sekitarnya maupun dari luar daerah. Dibuktikan dengan adanya SDIT dan SMPIT telah dijadikan tempat penelitian para civitas kampus maupun tempat studi banding oleh para praktisi pendidikan maupun sekolah lain baik dari dalam daerah maupun luar daerah Palangka Raya.

Maka dari hasil penelitian dan analisis peneliti menawarkan sebuah konsep model strategi manajemen humas dalam menciptakan School Branding pada sekolah Islam terpadu.

Gambar 3

Strategi Manajemen Humas

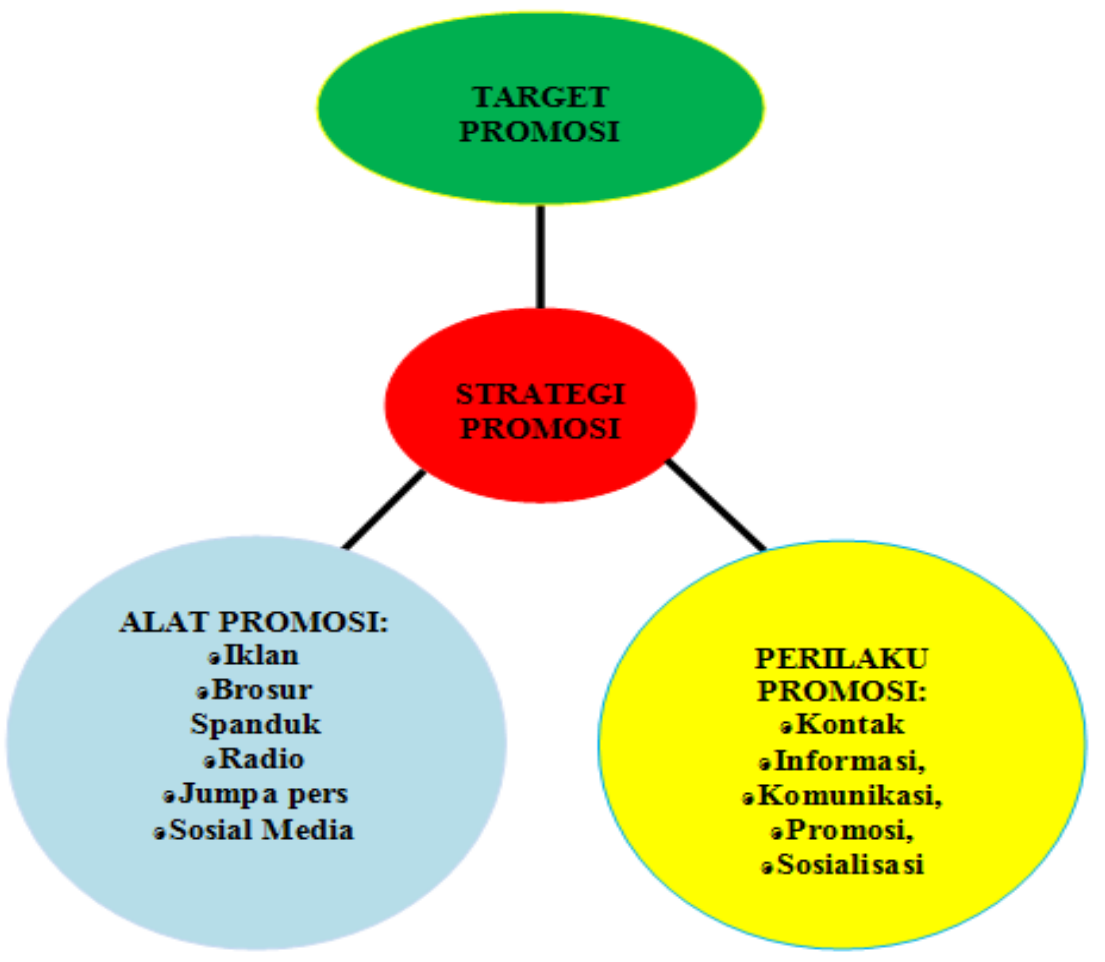


Gambar 4

Proses Formulasi Strategi Manajemen Humas

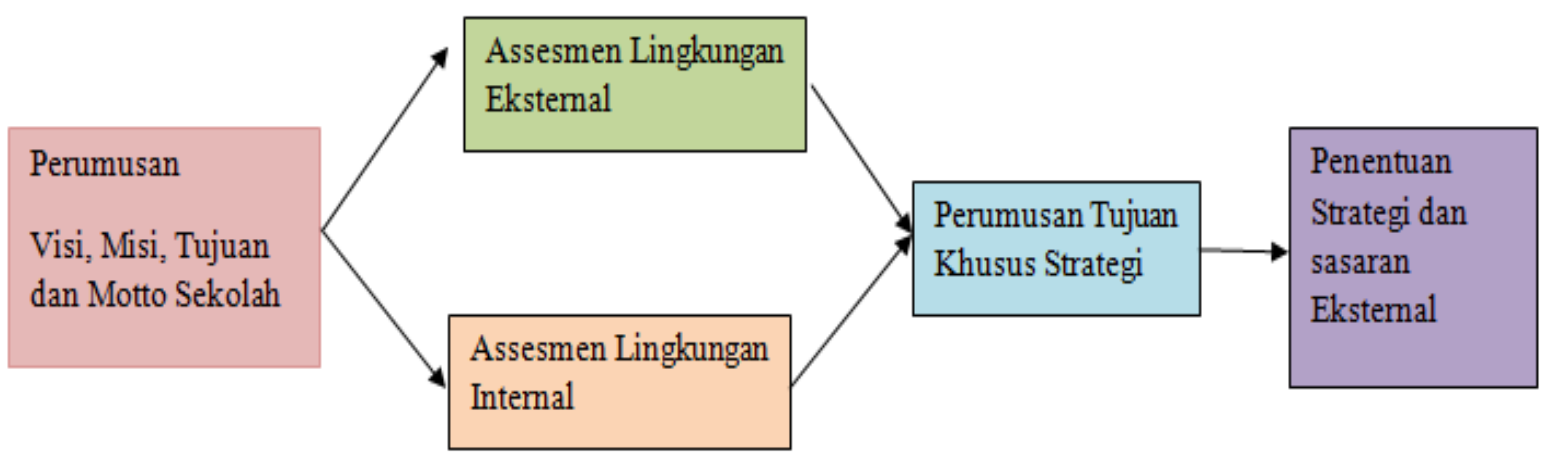

Gambar 5

Penawaran Konsep Model Strategi Manajemen Humas dalam Menciptakan School Branding Pada Sekolah Islam Terpadu

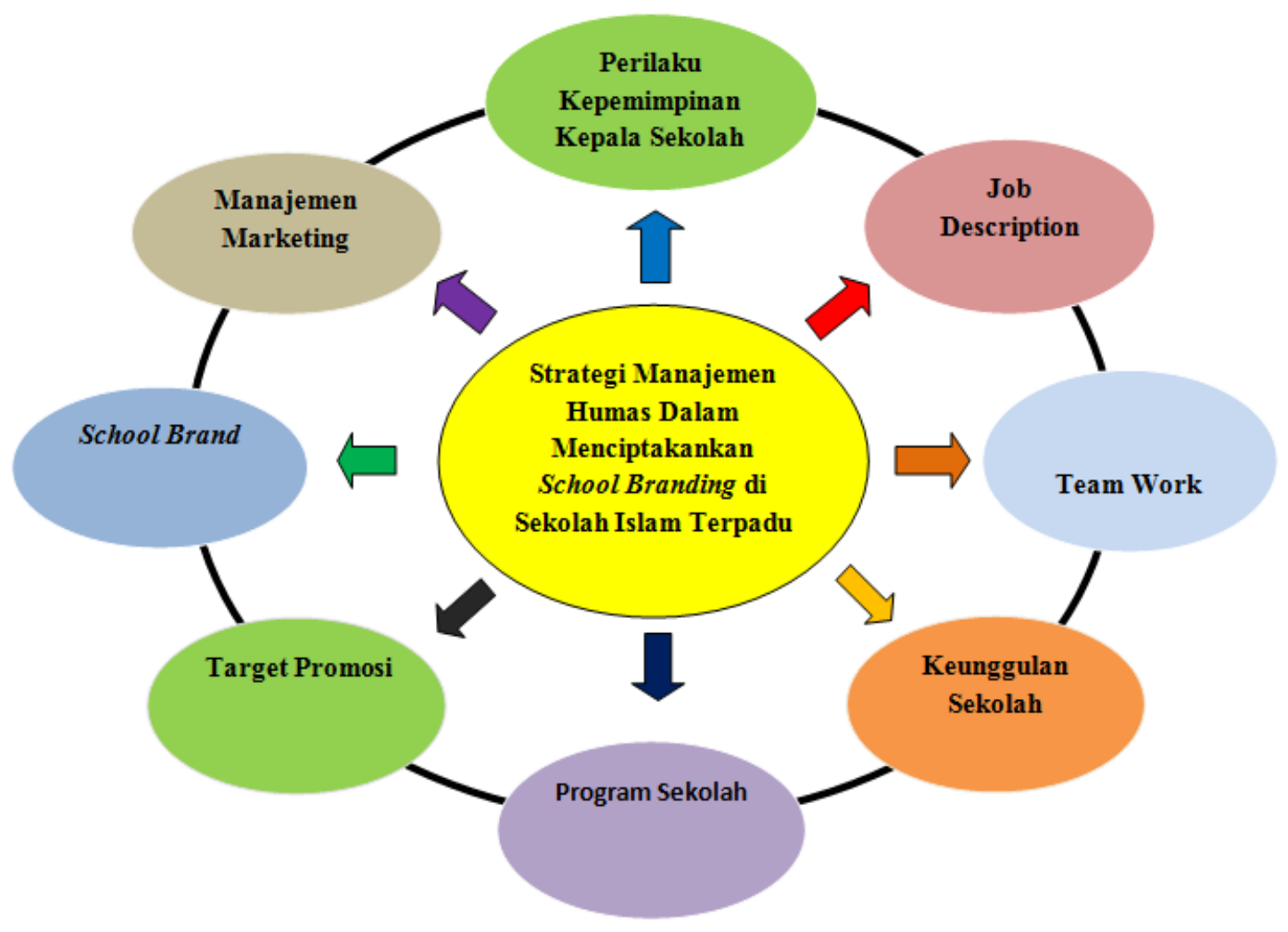

\section{F. PENUTUP}

Berdasarkan data yang telah dikumpulkan dan dilakukan analisis pembahasan tentang Strategi Manajemen Humas Dalam Menciptakan School Branding Pada Sekolah Dasar Islam Terpadu Al-Furqan Palangka Raya dan Sekolah Menengah Pertama Islam Terpadu Al-Ghazali Palangka Raya, maka dapat ditarik beberapa kesimpulan sebagai berikut : 
1. Bahwa kedua sekolah tersebut telah sukses dalam membangun citra positif sekolah ditengah masyarakat dengan strategi manajemen humasnya meskipun persaingan pada sekolah swasta sudah semakin meningkat.

2. Melalui perencanaan strategi, di implementasikan sesuai dengan perancangan, maka akan menghasilkan atau berdampak pada kemajuan sekolah itu sendiri.

Keberhasilan ini tidak lepas dari peran kepala sekolah sebagai leader, divisidivisi yang menyusun program kerja, para guru yang terlibat dalam mensukseskan setiap kegiatan dan tata usaha yang mengurus masalah administrasi, hingga terlaksananya strategi humas dalam mewujudkan School Branding pada sekolah Islam terpadu.

\section{REFERENSI}

Al Qur'an dan Tarjemahnya. (1977). Madinah: Khadim al-Haramain. Ahmad Tanzeh. (2009). Pengantar Metode Penelitian. Yogyakarta: Teras.

Bungin, Burhan. (2005) Analisis Data Penelitian Kualitatif. Jakarta: PT. Raja Grafindo Persada.

Faisal, Sanapiah. (2000). Penelitian Kualitatif, Makalah Kuliah Metode Penelitian. Malang: Program Pasacarsajana STAIN Malang

M. Linggar Anggoro. (2000). Teori \& Profesi Kehumasan serta Aplikasinya di Indonesia. Jakarta: Bumi Aksara.

Norman K. Denzin, \& Yvonna S. Lincoln. (1994). "Introduction: Entering the Field of Qualitative Research." In Norman K. Denzin and Yvonna S. Lincoln (Eds.) Handbook of Qualitative Research. Thousand Oaks: Sage Publications.

M. B. Miles, \& A. M. Huberman. (1992). Penerjemah : Rohidi, T.R. Analisis data Kualitatif: Buku Sumber Tentang Metode-Metode Baru. Jakarta: UI Press.

Santoso, Hari. (2012). Strategi Membangun "Brand" Sekolah. Diambil tanggal 11 Desember 2017 dari http:/ / dayasaingsekolah.blogspot.co.id/

Setyanto, Y., Anggarina, P. T., \& Valentina, A. (2017). Branding yang Dilakukan Humas pada Perguruan Tinggi Swasta. Jurnal Ilmu Sosial, Humaniora, Dan Seni, 1(1). Diambil dari

https://journal.untar.ac.id/index.php/jmishumsen/article/view/347

Sugiyono. (2012). Metode Penelitian Kuantitatif, Kualitatif, dan RED. Bandung: Alfabeta. Triwiyanto, Teguh. (2015). Manajemen Kurikulum dan Pembelajaran. Jakarta: Bumi Aksara.

Wahyudi. (2015). Inilah Brand Sekolah Muhammadiyah; Hafal Beberapa Juz Al-Quran dan Berakhlak Mulia. Diambil pada 11 April 2017 dari http://almuflihun.com/inilah-brand-sekolah-muhammadiyah-hafalbeberapa-juz-al-quran-dan-berakhlak-mulia/ 